\title{
Effects of abomasal infusion of tallow or camelina oil on responses to glucose and insulin in dairy cows during late pregnancy
}

\author{
S. Salin, ${ }^{* 1}$ J. Taponen, † K. Elo, ${ }^{*}$ I. Simpura, ${ }^{\star}$ A. Vanhatalo, ${ }^{\star}$ R. Boston,‡ and T. Kokkonen ${ }^{\star}$ \\ ${ }^{*}$ Department of Agricultural Sciences, PO Box 28, FI-00014 University of Helsinki, Finland \\ †Department of Production Animal Medicine, University of Helsinki, Paroninkuja 20, FI-04920 Saarentaus, Finland \\ łUniversity of Pennsylvania, New Bolton Center, Kennett Square 19348
}

\section{ABSTRACT}

Late pregnancy is associated with moderate insulin resistance in ruminants. Reduced suppression of lipolysis by insulin facilitates mobilization of nonesterified fatty acids (NEFA) from adipose tissue, resulting in elevated plasma NEFA concentrations. Decrease in dry matter intake (DMI) before parturition leads to accelerated lipomobilization and increases plasma NEFA, which may further impair insulin sensitivity. The aim of the study was to evaluate the effects of elevation of plasma NEFA concentration by abomasal infusions tallow (TAL) or camelina oil (CAM) on whole-body responses to exogenous glucose and insulin. We further assessed whether CAM, rich in C18:3n-3, enhances whole-body insulin sensitivity compared with TAL. Six late-pregnant, second-parity, rumen-cannulated dry Ayrshire dairy cows fed grass silage to meet 95\% of metabolizable energy requirements were used in a replicated $3 \times 3$ Latin square with 5 -d periods and 5 recovery days between each period. Treatments consisted of abomasal infusion of $500 \mathrm{~mL} / \mathrm{d}$ (430 g of lipids/d) of water (control), TAL, or CAM administered in 10 equal doses daily. Intravenous glucose tolerance test (IVGTT) and i.v. insulin challenge (IC) were performed on d 5 after 98 and $108 \mathrm{~h}$ of treatment infusions, respectively. Infusion of lipids increased basal plasma NEFA concentrations on d 5 (CAM: 0.25; TAL: 0.28; control: $0.17 \mathrm{mmol} / \mathrm{L})$. Following glucose injection, the rate of glucose clearance (CR) was lower in lipid-treated cows (CAM: 1.34; TAL: 1.48; control: $1.74 \% / \mathrm{min}$ ) and time to reach half-maximal glucose concentration $\left(\mathrm{T}_{1 / 2}\right)$ was longer (CAM: 54; TAL: 47; control: $42 \mathrm{~min}$ ). Similar responses were observed after insulin injection. Increased plasma NEFA concentration tended to decrease insulin secretion in IVGTT. Infusion of CAM increased plasma C18:3n-3 content (CAM: 26.4; TAL: 16.1; control: 20.9 $\mathrm{g} / 100 \mathrm{~g}$ of fatty acids). Data suggest that CAM had an

Received November 29, 2011

Accepted March 6, 2012.

${ }^{1}$ Corresponding author: siru.salin@helsinki.fi insulin-sensitizing effect, because the disposition index and insulin sensitivity index, derived from minimal model analysis, were higher in CAM than in TAL during IVGTT, and lower insulin concentrations during IC led to similar glucose clearance in CAM as in TAL. These results indicate that elevated plasma NEFA concentration per se induces whole-body insulin resistance in late-pregnant dry cows.

Key words: glucose tolerance, insulin resistance, latepregnant cow, nonesterified fatty acid

\section{INTRODUCTION}

Decreased circulating insulin concentrations and diminished insulin sensitivity of peripheral tissues promote nutrient partitioning to the fetal tissues in late pregnancy and to the mammary gland at the onset of lactation (Bell, 1995). Given that skeletal muscle and adipose tissue are the predominant insulin-sensitive tissues in ruminants (Weekes, 1991) and muscles account for majority of the insulin-dependent uptake of glucose (Pethick et al., 1984), altered responses to insulin in these tissues largely contribute to the advancement of moderate insulin resistance in late-pregnant ruminants (Bell, 1993; Petterson et al., 1993). This "glucose sparing effect of pregnancy," which results from homeorhetic changes, is a normal maternal adaptation to increased placental demands of nutrients (Bell and Bauman, 1997). Insulin resistance is distinguished by an abnormal response to standard levels of circulating insulin that is accompanied by glucose intolerance and decreased glucose uptake by peripheral insulin-sensitive tissues (Kahn, 1978). However, any further exacerbation of maternal insulin resistance induced by, for example, drastically decreased DMI before parturition, leading to accelerated lipomobilization and exaggerated plasma NEFA, is likely to contribute to the increase in susceptibility to metabolic disorders of periparturient dairy cows.

Reduced suppression of lipolysis by insulin facilitates mobilization of NEFA from adipose tissue, resulting in elevated plasma NEFA concentrations near calving and 
during early lactation (Bell, 1995). Plasma NEFA concentration starts to increase 2 to 1 wk prepartum and peaks at calving or during the first week of lactation (Grummer, 1993; Kokkonen et al., 2005). The decrease in plasma insulin concentration as calving approaches and the low insulin levels after calving facilitate the release of NEFA from adipose tissue. It is well understood that increased release of NEFA from adipose tissue and accumulation of intracellular lipid impair insulin signaling in skeletal muscle of humans (Boden, 2011). This leads to a decrease in insulin stimulated glucose transport, which may be mediated by a decrease in glucose transporter type 4 (GLUT-4) translocation or phosphorylation, or both (Boden and Chen, 1995; Dresner et al., 1999). Moreover, elevated NEFA concentrations, besides inducing insulin resistance, might produce a low-grade inflammation in peripheral tissues in humans (Boden, 2011). Elements that are involved in the development of insulin resistance in humans are related to those involved in the development of metabolic diseases in the periparturient ruminant. These factors include obesity, hyperinsulinemia, and hyperlipidemia (Hayirli, 2006). Indeed, the clearance rate of glucose during intravenous glucose tolerance test (IVGTT) was decreased in cows that were overconditioned and had higher plasma NEFA at calving compared with leaner cows (Holtenius et al., 2003). In addition, Bossaert et al. (2008) suggested that NEFA impair glucose-induced insulin secretion in dairy cows. Moreover, increased plasma NEFA concentrations during the last 2 wk of pregnancy were associated with greater incidences of displaced abomasum (LeBlanc et al., 2005; Ospina et al., 2010) and retained fetal membranes (LeBlanc et al., 2004). Elevated NEFA has also been related to hepatic lipogenesis and steatosis in dairy cows (Drackley, 1999; Overton and Waldron, 2004).

Several recent studies have focused on the effects of elevated plasma NEFA concentrations on insulin responsiveness and glucose tolerance in dry, nonpregnant dairy cows (e.g., Mashek et al., 2005; Pires et al., 2008; Brickner et al., 2009). In these studies, hyperlipidemia was induced by fasting or by infusions of different lipid sources or both. Pires et al. (2007b) showed that induction of hyperlipidemia by intravenous infusion of tallow (TAL) emulsion caused insulin resistance in nongestating, nonlactating Holstein cows. In addition, lowering plasma NEFA concentration by nicotinic acid infusion enhanced glucose clearance during IVGTT (Pires et al., 2007a). The authors concluded that impairment of glucose clearance during IVGTT and insulin challenge (IC) was likely due to increased supply of NEFA derived from triacylglycerol hydrolysis. They further speculated that as lipolysis is attenuated by insulin, any cause of insulin resistance in adipose tissue might further enhance mobilization of NEFA (Pires et al., 2007b). This, in turn, induces additional insulin resistance as part of a vicious cycle, a phenomenon also recognized in humans (Rosen and Spiegelman, 2006).

The beneficial effects of n-3 FA, especially those of marine origin, on insulin action in laboratory animals are well documented (Luo et al., 1996; Storlien et al., 2000; Lombardo and Chicco, 2006). For instance, n-3 FA are able to completely reverse the insulin resistance induced by a high-saturated-fat diet in rats (Storlien et al., 1991). In humans, effects of n-3 FA on insulin resistance are less consistent (Fedor and Kelley, 2009), and in farm animals, the available data are sparse. However, recent studies with nonlactating, nonpregnant cows have demonstrated that intravenous infusion of linseed oil, rich in C18:3n-3, decreased plasma insulin concentration (Mashek et al., 2005) and insulin secretion during IVGTT (Pires et al., 2008) compared with TAL infusion. Furthermore, linseed oil infusions enhance insulin sensitivity and the antilipolytic effect of insulin in adipose tissues of dairy cows (Mashek et al., 2005; Pires et al., 2008). Camelina (Camelina sativa L.), popularly known as false flax, presents a similar FA profile to linseed (Shukla et al., 2002).

The hyperinsulinemic-euglycemic glucose clamp technique is considered the gold standard test for evaluating insulin resistance or glucose intolerance in humans (Ferrannini and Mari, 1998; Muniyappa et al., 2008) as well as in animals (Ayala et al., 2006). However, the IVGTT can be conducted easily and is less stressful for the animal than the clamp technique. The IVGTT is commonly used to measure glucose intolerance in animals (Hayirli, 2006; Muniyappa et al., 2008). Impaired glucose tolerance is evidenced as a larger incremental area under the plasma glucose response curve (AUC) or a decreased clearance rate (CR), or both (Muniyappa et al., 2008). By incorporating minimal model analysis (Bergman and Bowden, 1981) into the glucose and insulin profiles obtained during IVGTT, it is possible to obtain more reliable, dynamic, indirectly measured estimates of insulin sensitivity. Minimal model estimates and variation coefficients correlate well with those obtained from the euglycemic clamp technique (Bergman et al., 1987; Steil et al., 1994).

To our knowledge, no information is available on the effects of induction of hyperlipidemia by abomasal infusions of lipids on insulin resistance and glucose tolerance during the dry period in late-pregnant dairy cows. Consequently, the key objective of this study was to evaluate the effects of elevated NEFA by abomasally infused TAL or camelina oil (CAM) on glucose tolerance and responsiveness to insulin during IVGTT and IC in nonlactating, 8-mo-pregnant Ayrshire dairy cows. Further, we hypothesized that infusion of CAM, a lipid 
Table 1. Chemical composition and calculated energy content of forages and lipid supplements

\begin{tabular}{lcccc}
\hline Item & Grass silage & Hay & Tallow $^{1}$ & Camelina oil $^{1}$ \\
\hline $\mathrm{DM}, \mathrm{g} / \mathrm{kg}$ & 293 & 756 & 100 & 100 \\
$\mathrm{Ash}, \mathrm{g} / \mathrm{kg}$ of DM & 68.0 & 72.3 & - & - \\
$\mathrm{CP}, \mathrm{g} / \mathrm{kg}$ of DM & 144 & 57.4 & - & - \\
Ether extract, g/kg of DM & 39.6 & 20.0 & 995 & - \\
$\mathrm{NDF}, \mathrm{g} / \mathrm{kg}$ of DM & 552 & 628 & - & - \\
$\mathrm{ADF}, \mathrm{g} / \mathrm{kg}$ of DM & 277 & $\overline{-}$ & - & 32.5 \\
$\mathrm{ME}, \mathrm{MJ} / \mathrm{kg}$ of DM & 11.3 & 9.20 & 32.3 & \\
\hline
\end{tabular}

${ }^{1}$ Values adopted from MTT Agrifood Research Finland (2006).

source rich in C18:3n-3, would enhance the insulin response compared with TAL infusion.

\section{MATERIALS AND METHODS}

\section{Animals, Diets, and Experimental Design}

The experimental procedures were conducted under the protocols approved by the National Animal Ethics Committee in Finland. Six nonlactating, second-parity, rumen-cannulated (100 mm i.d.; Bar Diamond, Parma, ID) Finnish Ayrshire dairy cows were used. Animals were dried off $73 \pm 4 \mathrm{~d}$ (mean $\pm \mathrm{SD}$ ) before their expected parturition date, housed in tie-stalls, and offered grass silage ad libitum until the initiation of the experiment. From drying-off to parturition, $0.2 \mathrm{~kg}$ of proprietary mineral and vitamin supplement (Tunnu-Melli, Raisio Feed Ltd., Raisio, Finland) was top-dressed once daily on forage. The supplement contained $5.1 \mathrm{MJ} / \mathrm{kg}$ of ME; $(\mathrm{g} / \mathrm{kg})$ magnesium (101), sodium (60), phosphorus (55), calcium $(24) ;(\mathrm{mg} / \mathrm{kg})$ zinc $(1,500)$, manganese $(550)$, vitamin E (500), copper (400), iodine (50), cobalt (30), selenium (18); (IU $/ \mathrm{kg}$ ) vitamin A $(180,000)$, vitamin $\mathrm{D}_{3}(35,000)$. The mineral mixture contained $140 \mathrm{~g} / \mathrm{kg}$ of molassed beet pulp, $120 \mathrm{~g} / \mathrm{kg}$ of wheat bran, and 110 $\mathrm{g} / \mathrm{kg}$ of sugar beet molasses as carrier.

Cows were randomly assigned to treatments in a replicated $3 \times 3$ Latin square design $45 \pm 3 \mathrm{~d}$ and $43 \pm 4 \mathrm{~d}$ (mean $\pm \mathrm{SD}$ ) before the expected and actual dates of calving, respectively. The length of each experimental period was $5 \mathrm{~d}$. To reduce carry-over effects, a 5-d washout period followed each experimental period. The treatments consisted of abomasal infusions of water (control), bovine TAL, or CAM. The lipids were provided by Raisio Feed Ltd. At the end of the experimental periods, cows were $19 \pm 4 \mathrm{~d}$ (mean $\pm \mathrm{SD}$ ) away from their actual calving dates.

The chemical composition and calculated energy content of forages and lipid supplements are shown in Table 1. Cows were fed a mixture of grass silage and grass hay (80\%:20\% of DM) twice daily at 0700 and $1700 \mathrm{~h}$. The amounts offered were recorded daily and no refusals were observed. During the experimental periods, energy intake was calculated to meet $90 \%$ of $\mathrm{ME}$ requirements of 8-mo-pregnant cows (MTT Agrifood Research Finland, 2006). The energy content of lipid infusions was taken into account in the calculation of individual energy allowances. The determined in vitro OM digestibility of the grass silage was, however, higher than that estimated from samples of the parent herbage collected during ensiling, leading to a final energy allowance of $95 \%$ of ME requirements. During the washout period, cows were fed the same forage mixture to meet energy requirements. Feeding was suspended 1 $\mathrm{h}$ prior to and during IVGTT and IC.

The amount of water or lipid administered was 500 $\mathrm{mL} / \mathrm{d}$ (approximately $430 \mathrm{~g} / \mathrm{d}$ of TAL or CAM), which was infused through an abomasal line attached to the rumen cannula plug. The daily dose was infused in 10 equal portions ( $50 \mathrm{~mL}$ at once) with a $100-\mathrm{mL}$ syringe, administered every second hour between 0600 and $2400 \mathrm{~h}$. The infusion line (polyvinyl chloride tubing, i.d. $6.0 \mathrm{~mm}$ ) was anchored in the abomasum with a sinker (polyethylene bottles filled with ball bearings, approximately $450 \mathrm{~g}$ ) attached to the distal end of the line. Placement of the infusion line was checked twice daily by hand. For the tallow infusion, the daily amount of tallow was melted in a convection oven at $50^{\circ} \mathrm{C}$ for $12 \mathrm{~h}$ from the previous evening forward, and stored at the same temperature during the day of infusion. To avoid solidification of tallow, the lipid- and water-filled syringes were kept in a water bath $\left(44^{\circ} \mathrm{C}\right)$ until lipid supplements were infused into the abomasum. Boiled tap water $\left(150 \mathrm{~mL} ; 37^{\circ} \mathrm{C}\right)$ and ethanol $(10 \mathrm{~mL})$ were infused simultaneously with the control treatments to flush the abomasal lines. The liquids were infused in following sequence: $50 \mathrm{~mL}$ of water, $50 \mathrm{~mL}$ of lipid (water in control treatment), $50 \mathrm{~mL}$ of water, $10 \mathrm{~mL}$ of ethanol, and $50 \mathrm{~mL}$ of water.

Cows were weighed on 2 consecutive days before the initiation of every experimental period, and BCS was recorded at the beginning and end of the experiment. The initial BW was $614 \pm 30 \mathrm{~kg}$ and the average BCS $3.66 \pm 0.15$ (mean $\pm \mathrm{SD})$. 


\section{Sampling and Analysis of Feed and Feces}

The forage mixture was prepared every fourth day during the experiment using a vertical mixer (CutMix, Pellon Group, Ylihärmä, Finland). Representative samples of silage and hay were collected during mixing and stored at $-20^{\circ} \mathrm{C}$. Dry matter content of the forages was determined by oven drying $\left(105^{\circ} \mathrm{C}, 24 \mathrm{~h}\right)$ immediately after sample collection. Content of $\mathrm{OM}$ was determined by ashing at $600^{\circ} \mathrm{C}$, and NDF was determined using sodium sulfite and $\alpha$-amylase and reported on an ash-free basis (VanSoest et al., 1991). Contents of $\mathrm{CP}$ and ether extract (EE) were determined using standard procedures (AOAC, 1995). In vitro OM digestibility of silage was determined using a method based on pepsin-cellulase solubility (Nousiainen et al., 2003). Dry matter content of silage was correct for the loss of volatiles according to Huida et al. (1986). The lactic acid content of silages was measured by using a colorimetric method (Barker and Summerson, 1941), and the VFA of silage were determined by gas chromatography (Hewlett Packard 5890 Series II, Palo Alto, CA) as described by Huhtanen et al. (1998). Ethanol concentration was measured with an enzymatic kit (Cat No. 10176290 035, Boehringer Mannheim GmbH, Mannheim, Germany) and protocol supplied by the manufacturer using the UV-spectrophotometer (Shimadzu UV mini 1240, Shimadzu Europa GmbH, Duisburg, Germany). Acid insoluble ash (AIA) concentration of feed was determined by acid hydrolysis (van Keulen and Young, 1977).

Whole-tract apparent digestibilities of the diets were determined using AIA as an internal marker (Van Keulen and Young, 1977). During each experimental period, fecal samples were collected from the rectum twice daily at 0730 and $1730 \mathrm{~h}$ and stored at $-20^{\circ} \mathrm{C}$. At the end of each period, samples were pooled on an individual cow basis. Fecal DM, CP, NDF, EE, and AIA contents were determined in dried samples using the same procedures as in feeds.

The ME content of silage was predicted from in vivo digestible $\mathrm{OM}$ intake assuming a ME content of $16 \mathrm{MJ} /$ $\mathrm{kg}$ of digestible OM (MAFF, 1975) and the ME content of hay by following equation:

$$
\mathrm{ME}(\mathrm{MJ} / \mathrm{kg})=0.169 \times \text { digestible } \mathrm{OM}-1.05 .
$$

\section{Blood Sampling, IVGTT, IC, and Analysis of Blood}

On d 4 of each period, both jugular veins were catheterized with an indwelling catheter [left: Intraflon 14 G (Vygon, Ecouen, France); right: homemade catheter made of silicone tube]. A polyvinyl chloride elongation tube (Connecta, BD Medical, Franklin Lakes, NJ) was connected to both catheters to avoid manipulation of the cows during blood sampling.

On d 5 of each experimental period at $0630 \mathrm{~h}$ (before morning feeding), blood samples were collected via catheters using disposable $10-\mathrm{mL}$ syringes into 10-mL test tubes (Vacutainer; BD Medical) containing EDTA as an anticoagulant. On the same day at $0900 \mathrm{~h}$, IVGTT were performed by i.v. administration of 0.25 $\mathrm{g}$ of glucose $/ \mathrm{kg}$ of BW (Glucos $300 \mathrm{mg} / \mathrm{mL}, \mathrm{B}$. Braun Melsungen AG, Melsungen, Germany) over $4.0 \pm 1.8$ min (mean \pm SD). Insulin challenges were performed on the same day at $1900 \mathrm{~h}$ by i.v. administration of 0.1 IU of insulin/kg of BW (100 IU/mL; Humulin Regular, human insulin rDNA origin; Lilly Pharma Fertingung und Distribution GmbH \& Co. KG, Giessen, Germany). Catheters were flushed with heparin solution $(1 \mathrm{~mL}$ of heparin/100 $\mathrm{mL}$ of $0.9 \% \mathrm{NaCl}$ ) immediately after infusions or blood samplings.

Blood samples were collected at $-15,-5,5,10,15$, $20,30,40,50,60,90$, and 120 min relative to administration of glucose or insulin and additionally at 150 and $180 \mathrm{~min}$ after glucose infusions. Blood samples were collected from the right jugular vein, whereas the infusions of glucose for the IVGTT and insulin for the IC were administered into the left jugular vein. The treatment infusions were suspended during IVGTT and IC sampling. Treatments were administered for 98 and $108 \mathrm{~h}$ before IVGTT and IC, respectively.

Blood was centrifuged at $2,220 \times g$ for $10 \mathrm{~min}$ to separate plasma. The plasma was stored in plastic tubes at $-20^{\circ} \mathrm{C}$ until analysis for concentrations of NEFA, glucose, and insulin. Plasma NEFA concentration was determined with an enzymatic colorimetric acyl-CoA synthetase (ACS)-acyl-CoA oxidase (ACOD) method [NEFA-HR(2) kit, Wako Chemicals GmbH, Neuss, Germany], according to the manufacturer's instructions. Plasma concentration of glucose was analyzed with an enzymatic, colorimetric glucose oxidase-peroxidase (GOD-POD) method (Glucose GOD-POD kit, Thermo Fisher Scientific Oy, Vantaa, Finland; Trinder, 1969; Barham and Trinder, 1972). The analyses were performed on an automatic chemistry analyzer (KONE Pro Selective Chemistry Analyzer, Thermo Electron Oy). Intra- and interassay CV for NEFA determination were 1.2 and $6.2 \%$ (low), 0.9 and $2.3 \%$ (high). Plasma insulin concentration was measured with a RIA kit (PI-12K, Millipore Oy, Espoo, Finland; Morgan and Lazarow, 1963). Intraassay CV for insulin determination was $7.0 \%$ and interassay CV was 9.3 and $4.8 \%$ for low and medium concentration, respectively.

Total FA of plasma samples taken on d 5 were analyzed on Waters Acquity ultra performance liquid chromatography (UPLC) system (Waters, Milford, MA). To $100 \mu \mathrm{L}$ of plasma was added $100 \mu \mathrm{L}$ of nonadecanoic 
acid $(1 \mathrm{~m} M)$ in ethanol as internal standard followed by $650 \mu \mathrm{L}$ of ethanol and $250 \mu \mathrm{L}$ of $4 \mathrm{M} \mathrm{NaOH}$ solution. Vortexed solution was heated at $60^{\circ} \mathrm{C}$ for $1 \mathrm{~h}$. One milliliter of $2 \mathrm{M} \mathrm{HCl}$ and $1 \mathrm{~mL}$ of water were added to the cooled solution. After vortexing, samples were centrifuged $\left(1,500 \times g\right.$ for $10 \mathrm{~min}$ at $\left.20^{\circ} \mathrm{C}\right)$. Hydrolysis solution was extracted twice with hexane $(1 \mathrm{~mL})$. Hexane was dried by passing it through solid $\mathrm{Na}_{2} \mathrm{SO}_{4}$ inserted into a Pasteur pipette over cotton wool. Hexane was evaporated by flush of nitrogen at $60^{\circ} \mathrm{C}$.

The UPLC samples were prepared by addition of $100 \mu \mathrm{L}$ of 4-nitrophenylhydrazine $40 \mathrm{~m} M$ in $0.1 M$ $\mathrm{HCl}$ acetonitrile solution to evaporated residue. After vortexing, $100 \mu \mathrm{L}$ of EDC $N$-(3-dimethylaminopropyl)$N^{\prime}$-ethylcarbodiimide hydrochloride $250 \mathrm{mM}$ in $3 \%$ pyridine ethanol solution was added to previous solution, vortexed, and warmed at $60^{\circ} \mathrm{C}$ for $30 \mathrm{~min}$.

\section{Analysis of FA Composition of Camelina Oil and Tallow}

Camelina oil (13.2 mg) and tallow (13.7 mg) were transferred into a $20-\mathrm{mL}$ measure flask followed by dissolution in $1 \mathrm{~mL}$ of toluene. The flasks were filled to 20 $\mathrm{mL}$ with ethanol. To 2 separate vessels were added 500 $\mu \mathrm{L}$ of both the previous solutions followed by $100 \mu \mathrm{L}$ of internal standard nonadecanoic acid $(1 \mathrm{mM})$ in ethanol, $150 \mu \mathrm{L}$ of ethanol, and $250 \mu \mathrm{L}$ of $4 M \mathrm{NaOH}$. Hydrolysis vessels were heated at $60^{\circ} \mathrm{C}$ for $60 \mathrm{~min}$. Hydrolysis mixtures were acidified by addition of $1 \mathrm{~mL}$ of $2 \mathrm{M} \mathrm{HCl}$ solution and $3 \mathrm{~mL}$ of water. Solutions were extracted 3 times with hexane $(1 \mathrm{~mL})$. Hexane phases were isolated and dried (filtration through Pasteur pipette filled with $\mathrm{Na}_{2} \mathrm{SO}_{4}$ ). Hexane was evaporated by flush of nitrogen at $60^{\circ} \mathrm{C}$. Residues were redissolved in $200 \mu \mathrm{L}$ of ethanol.

Samples for UPLC were prepared by addition of $50 \mu \mathrm{L}$ of 4-nitrophenylhydrazine $40 \mathrm{~m} M$ in $0.1 M$ $\mathrm{HCl}$ acetonitrile solution to $25 \mu \mathrm{L}$ of sample. After vortexing, $50 \mu \mathrm{L}$ of EDC $N$-(3-dimethylamino-propyl)$N^{\prime}$-ethylcarbodiimide hydrochloride $250 \mathrm{mM}$ in $3 \%$ pyridine ethanol solution was added to the previous solution, vortexed, and warmed at $60^{\circ} \mathrm{C}$ for $30 \mathrm{~min}$.

All FA analyses were performed on Waters Acquity UPLC system, including binary solvent manager, sample manager, column compartment, and photo diode array detector, connected with Waters Empower 2 software. An Acquity UPLC BEH C18 column $(150 \mathrm{~mm} \times 2.1$ $\mathrm{mm}$, i.d. of $1.7 \mu \mathrm{m}$ ) was used. The column temperature was maintained at $50^{\circ} \mathrm{C}$. The standards and samples were separated using a gradient mobile phase consisting of water (A) and acetonitrile (B). The gradient composition was 0 to $1 \mathrm{~min}, 70 \% \mathrm{~B}$; 1 to $5 \mathrm{~min}, 70-90 \% \mathrm{~B}$; 5 to $6 \mathrm{~min}, 90 \% \mathrm{~B}$; 6 to $6.5 \mathrm{~min}, 90-70 \% \mathrm{~B} ; 6.5$ to 7.5 $\mathrm{min}, 70 \% \mathrm{~B}$. The flow rate was $0.6 \mathrm{~mL} / \mathrm{min}$ for $1 \mathrm{~min}$; then, it increased linearly to $0.7 \mathrm{~mL} / \mathrm{min}$ to $5 \mathrm{~min}$, was held at $0.7 \mathrm{~mL} / \mathrm{min}$ to $6 \mathrm{~min}$, and decreased linearly to $0.6 \mathrm{~mL} / \mathrm{min}$ to $6.5 \mathrm{~min}$. The injection volume was $1 \mu \mathrm{L}$, and the detection wavelength was $400 \mathrm{~nm}$. Fatty acids were identified according to the known peaks of camelina oil and tallow. Amount of FA was analyzed using calibration curve of 4-nitrophenylhydrazine derivative of hexadecanoic acid.

\section{Calculations and Statistical Analysis}

Plasma glucose, insulin, and NEFA responses to metabolic challenges were calculated as net incremental area under the response curve (AUC; mmol/L $\times$ min for glucose and NEFA; $\mu \mathrm{IU} / \mathrm{mL} \times \min$ for insulin) during the first 60 and $180 \mathrm{~min}$ of IVGTT and 30, 60, and $120 \mathrm{~min}$ of IC using actual concentration values. The AUC was calculated using SAS version 9.1 (2004; SAS Institute Inc., Cary, NC) using the trapezoidal rule (Shiang, 2004), where basal concentrations were determined as the mean concentration of blood samples taken before ( -15 and -5 min) IVGTT and IC. Insulin and glucose peaks and nadir concentrations were determined. To further estimate the clearance of metabolites during IVGTT and IC, clearance rate $(\mathrm{CR} ; \% / \mathrm{min})$ and time to reach half-maximal concentration $\left(\mathbf{T}_{1 / 2}\right.$; min) of metabolites were calculated using PROC NLIN of SAS (version 9.1). Exponential curves for glucose, insulin, and NEFA concentrations during metabolic challenges were fitted using the following equation:

$$
\mathrm{F}(\mathrm{t})=\mathrm{A} \times \mathrm{e}^{(-\mathrm{k} \times \mathrm{t})}
$$

where $\mathrm{F}(\mathrm{t})$ is the metabolite concentration at time $\mathrm{t}$; $\mathrm{A}$ is the estimated maximum value of glucose or basal value of insulin or NEFA for IVGTT, and estimated maximum insulin concentration or basal glucose or NEFA concentration for IC; $\mathrm{t}$ is the time ( $\mathrm{min})$; and $\mathrm{k}$ is the regression coefficient. The following parameters were calculated:

$$
\begin{gathered}
\mathrm{T}_{1 / 2}=(\ln [2] / \mathrm{CR}) \times 100, \\
\mathrm{CR}=100 \times(\ln [\mathrm{ta}]-\ln [\mathrm{tb}]) /(\mathrm{tb}-\mathrm{ta}),
\end{gathered}
$$

where [ta] is the concentration of metabolite at time a (ta), and [tb] is the concentration of metabolite at time b (tb).

For IVGTT, the insulin sensitivity index $\left(\mathbf{S}_{\mathbf{I}} ; \times 10^{-4}\right.$ $\left.\min ^{-1} / \mu \mathrm{IU} / \mathrm{mL}\right)$, acute insulin response $\left(\mathbf{A I R}_{\mathrm{G}} ; \mu \mathrm{IU} /\right.$ $\mathrm{mL}$ ), and disposition index (DI; the product of $\mathrm{S}_{\mathrm{I}}$ and $\mathrm{AIR}_{\mathrm{G}}$ ) were obtained by analyzing the glucose and insu- 
Table 2. Effect of abomasal infusion of water (control), tallow (TAL), or camelina oil (CAM) on feed intake and nutrient digestibilities

\begin{tabular}{|c|c|c|c|c|c|c|}
\hline Item & \multicolumn{3}{|c|}{ Treatment } & SEM & \multicolumn{2}{|c|}{$P$-value } \\
\hline \multicolumn{7}{|l|}{ Intake } \\
\hline $\mathrm{CP}, \mathrm{g} / \mathrm{d}$ & 1,111 & 940 & 934 & 14.3 & $<0.001$ & 0.22 \\
\hline Ether extract, $\mathrm{g} / \mathrm{d}$ & 314 & 697 & 694 & 3.90 & $<0.001$ & 0.63 \\
\hline $\mathrm{NDF}, \mathrm{g} / \mathrm{d}$ & 4,930 & 4,175 & 4,149 & 60.5 & $<0.001$ & 0.23 \\
\hline $\mathrm{CP}, \mathrm{g} / \mathrm{kg}$ & 650 & 657 & 665 & 10.5 & 0.35 & 0.51 \\
\hline Ether extract, $\mathrm{g} / \mathrm{kg}$ & 470 & 704 & 754 & 14.5 & $<0.001$ & 0.03 \\
\hline NDF, $g / \mathrm{kg}$ & 654 & 641 & 659 & 18.9 & 0.81 & 0.35 \\
\hline ME intake, MJ/d & 95.2 & 94.4 & 94.1 & 1.17 & 0.04 & 0.48 \\
\hline ME balance, MJ/d & -3.5 & -4.2 & -4.6 & 0.25 & 0.01 & 0.17 \\
\hline
\end{tabular}

lin concentrations of individual animals calculated with the MinMod program (Boston et al., 2003) using the minimal model (Bergman and Bowden, 1981). The index $\mathrm{S}_{\mathrm{I}}$ represents the effect of plasma insulin to increase the fractional disappearance rate of glucose; $\mathrm{AIR}_{\mathrm{G}}$ is the first-phase insulin response to glucose load; and DI reflects the ability of the $\beta$-cells of the pancreatic islets to compensate for insulin resistance by increasing $\beta$-cell responsiveness.

For evaluation of NEFA disposal during IVGTT, a NEFA model (Boston and Moate, 2008) was used to obtain following parameters: $\mathbf{S}_{\mathbf{F F A}}(\mathrm{mmol} / \mathrm{L}$ per min) describes the maximal rate of net provision of NEFA to the plasma pool, and $\mathbf{K}_{\mathbf{F F A}}(\% / \mathrm{min})$ describes the rate at which NEFA leaves the plasma pool.

Experimental data were analyzed by ANOVA using the Mixed procedure of SAS (version 9.1, SAS Institute Inc.). The model included fixed effects of treatment, square and period within square and random effects of cow within square. Period was removed from the statistical model when declared nonsignificant at $P>$ 0.20. Predefined orthogonal contrasts were used to test

Table 3. Fatty acid composition (g/100 g of FA) of lipid supplements ${ }^{1}$

\begin{tabular}{lrc}
\hline Fatty acid & Tallow & Camelina oil \\
\hline C14:0 & 3.9 & 0.4 \\
C16:0 & 27.2 & 6.1 \\
C16:1 & 3.5 & 0.0 \\
C18:0 & 23.5 & 2.7 \\
C18:1 & 36.9 & 13.5 \\
C18:2 & 1.5 & 17.1 \\
C18:3n-3 & 0.8 & 37.1 \\
C18:3n-6 & 1.2 & 1.1 \\
C19:0 & 0.0 & 0.0 \\
C20:0 & 0.0 & 1.4 \\
C20:1 & 0.0 & 13.4 \\
C20:2 & 1.3 & 2.1 \\
C20:3 & 0.0 & 1.8 \\
C22:1 & 0.0 & 3.2 \\
\hline
\end{tabular}

${ }^{1}$ Raisio Feed Ltd. (Raisio, Finland). the effects of lipid infusions: lipids versus control and CAM versus TAL. All values in the tables are reported as least squares means and SEM. Treatment effects were declared significant at $P<0.05$, and tendencies for treatment effects were declared at $0.05 \leq P<$ 0.10 . Logarithmic transformation was used to correct for deviations from normality and homoscedasticity of residuals, when needed. In those cases, least squares means and SEM are reported from statistical analysis of untransformed values and $P$-values from analysis of transformed data.

\section{RESULTS}

\section{Feed Intake, Nutrient Digestibility, and Energy Balance}

The daily intakes and total-tract digestibilities of $\mathrm{DM}, \mathrm{CP}, \mathrm{EE}$, and NDF, as well as ME intake and ME balance are shown in Table 2. As expected, daily intakes of forage DM, CP, and NDF were significantly smaller and EE intake greater $(P<0.001)$ during lipid infusions compared with control treatments. Treatments did not affect the apparent digestibility of feed components, except for the expected greater digestibility of EE during lipid infusions $(P<0.001)$. However, infusion of CAM increased the digestibility of EE compared with TAL $(P=0.03)$. Intake of $\mathrm{ME}$ was smaller $(1 \mathrm{MJ} / \mathrm{d} ; P=$ $0.04)$ and $\mathrm{ME}$ balance was more negative $(P=0.01)$ during lipid infusions compared with control infusion.

\section{FA Composition of Lipid Supplements}

The FA profiles of infused lipid sources are shown in Table 3. Tallow contained, in total, $87.6 \%$ of $\mathrm{C} 16: 0$, C18:0, and C18:1, which are the most common FA in ruminant tissue, whereas $\mathrm{C} 18: 3 \mathrm{n}-3$ accounted for $0.8 \%$ of the total FA. In CAM, total PUFA accounted for $59.2 \%$ and C18:3n-3 accounted for $37.1 \%$ of all FA. 
Table 4. Effect of abomasal infusion of water (control), tallow (TAL), or camelina oil (CAM) on long-chain fatty acids in plasma on d 5

\begin{tabular}{|c|c|c|c|c|c|c|}
\hline FA $(\mathrm{g} / 100 \mathrm{~g}$ of FA identified $)$ & \multicolumn{3}{|c|}{ Treatment } & SEM & \multicolumn{2}{|c|}{$P$-value } \\
\hline C14:0 & 2.0 & 1.7 & 0.9 & 0.072 & $<0.001$ & $<0.001$ \\
\hline C16:1 & 3.4 & 3.6 & 1.7 & 0.22 & $<0.01$ & $<0.001$ \\
\hline C18:0 & 16.6 & 14.7 & 14.1 & 0.544 & $<0.01$ & 0.466 \\
\hline C18:1 & 11.0 & 19.7 & 6.78 & 0.691 & 0.019 & $<0.001$ \\
\hline C20:1 & 0.02 & 0.01 & 1.4 & 0.12 & $<0.01$ & $<0.001$ \\
\hline $\mathrm{C} 20: 2$ & 0.36 & 0.17 & 0.56 & 0.066 & 0.982 & $<0.01$ \\
\hline $\mathrm{C} 16: 0+\mathrm{C} 18: 0+\mathrm{C} 18: 1$ & 42.2 & 50.1 & 30.8 & 1.32 & 0.302 & $<0.001$ \\
\hline Total SFA & 31.5 & 30.8 & 24.1 & 0.849 & $<0.01$ & $<0.001$ \\
\hline Total MUFA & 13.7 & 22.4 & 9.47 & 0.812 & 0.036 & $<0.001$ \\
\hline Total PUFA & 49.7 & 43.0 & 63.1 & 1.46 & 0.091 & $<0.001$ \\
\hline
\end{tabular}

\section{Plasma FA Composition on d 5}

Infusion of lipid supplements (CAM or TAL) altered plasma total long-chain fatty acid (LCFA) profiles on d 5 of experimental periods (Table 4). All FA detected, with the exception of C18:2, C18:3, and C20:2 were significantly differently represented in plasma with lipid infusions compared with control $(P<0.05)$. Infusion of CAM significantly increased the proportion of plasma PUFA (CAM vs. TAL; $P<0.001$ ), and plasma C18:3n-3 content during CAM infusion was increased by approximately 10.3 percentage units compared with that following TAL infusion $(P<0.001)$. Moreover, infusion of CAM decreased the percentages of C14:0, C16:0, C16:1, and C18:1 in plasma (CAM vs. TAL; $P<$ 0.001), whereas infusion of TAL increased the proportion of SFA and MUFA (CAM vs. TAL; $P<0.001$ ), of which the percentage of C18:1 was increased by approximately 13 percentage units compared with that in TAL $(P<0.001)$.

\section{Blood Plasma Metabolites on d 5}

Abomasal infusion of lipids caused an increase in plasma NEFA concentration $(P=0.001)$ during experimental periods (Table 5). However, lipid source (CAM vs. TAL) did not affect plasma NEFA concentration.
No significant treatment effects were found on plasma glucose, insulin, or BHBA concentrations on d 5 .

\section{Response to IVGTT}

Treatment effects on metabolic responses during IVGTT are given in Table 6. Basal glucose concentration tended to be higher during lipid infusions $(P=$ $0.07)$ and glucose peak concentration was lower $(P=$ 0.02 ) for lipid treatments during IVGTT (Figure 1A). The CR of glucose during the first $60 \mathrm{~min}\left(\mathbf{C R}_{60}\right)$ of IVGTT decreased $(P=0.03)$, and time to reach halfmaximal glucose concentration $\left(\mathrm{T}_{1 / 2}\right)$ tended to be greater for lipid infusions than for control $(P=0.06)$. Glucose AUC was not affected by lipid infusions during IVGTT.

Lipid treatments affected insulin concentration during IVGTT (Table 6; Figure 1B). Basal insulin tended to be lower $(P=0.06)$ and insulin AUC during the first $60 \mathrm{~min}\left(\mathbf{A U C}_{6 \mathbf{0}}\right)$ of IVGTT was decreased $(P=$ 0.02) during lipid treatments compared with control. Furthermore, insulin AUC during IVGTT tended to be smaller during CAM infusion $(P<0.10)$ relative to TAL infusion (Figure 2). In contrast, insulin $\mathrm{CR}_{60}$ was greater during lipid infusions $(P=0.04)$. Moreover, the infusion of CAM affected $\mathrm{S}_{\mathrm{I}}$ and DI derived from the minimal model; both $\mathrm{S}_{\mathrm{I}}(P=0.05)$ and DI $(P=0.04)$

Table 5. Effect of abomasal infusion of water (control), tallow (TAL), or camelina oil (CAM) on plasma metabolites on d 5

\begin{tabular}{|c|c|c|c|c|c|c|}
\hline \multirow[b]{2}{*}{ Item } & \multicolumn{3}{|c|}{ Treatment } & \multirow[b]{2}{*}{ SEM } & \multicolumn{2}{|c|}{$P$-value } \\
\hline & Control & TAL & CAM & & Lipids vs. Control & CAM vs. TAL \\
\hline Glucose $(\mathrm{mmol} / \mathrm{L})$ & 4.1 & 4.3 & 4.3 & 0.13 & 0.36 & 0.86 \\
\hline Insulin $(\mu \mathrm{IU} / \mathrm{mL})^{\prime}$ & 16.8 & 14.7 & 12.7 & 2.02 & 0.15 & 0.41 \\
\hline NEFA (mmol/L) & 0.17 & 0.28 & 0.25 & 0.024 & 0.001 & 0.19 \\
\hline BHBA (mmol/L) & 0.49 & 0.57 & 0.55 & 0.067 & 0.33 & 0.88 \\
\hline
\end{tabular}


Table 6. Effect of abomasal infusion of water (control), tallow (TAL), or camelina oil (CAM) on plasma glucose, insulin, and NEFA responses to i.v. glucose tolerance test (IVGTT; $0.25 \mathrm{~g}$ of glucose i.v. $/ \mathrm{kg}$ of BW)

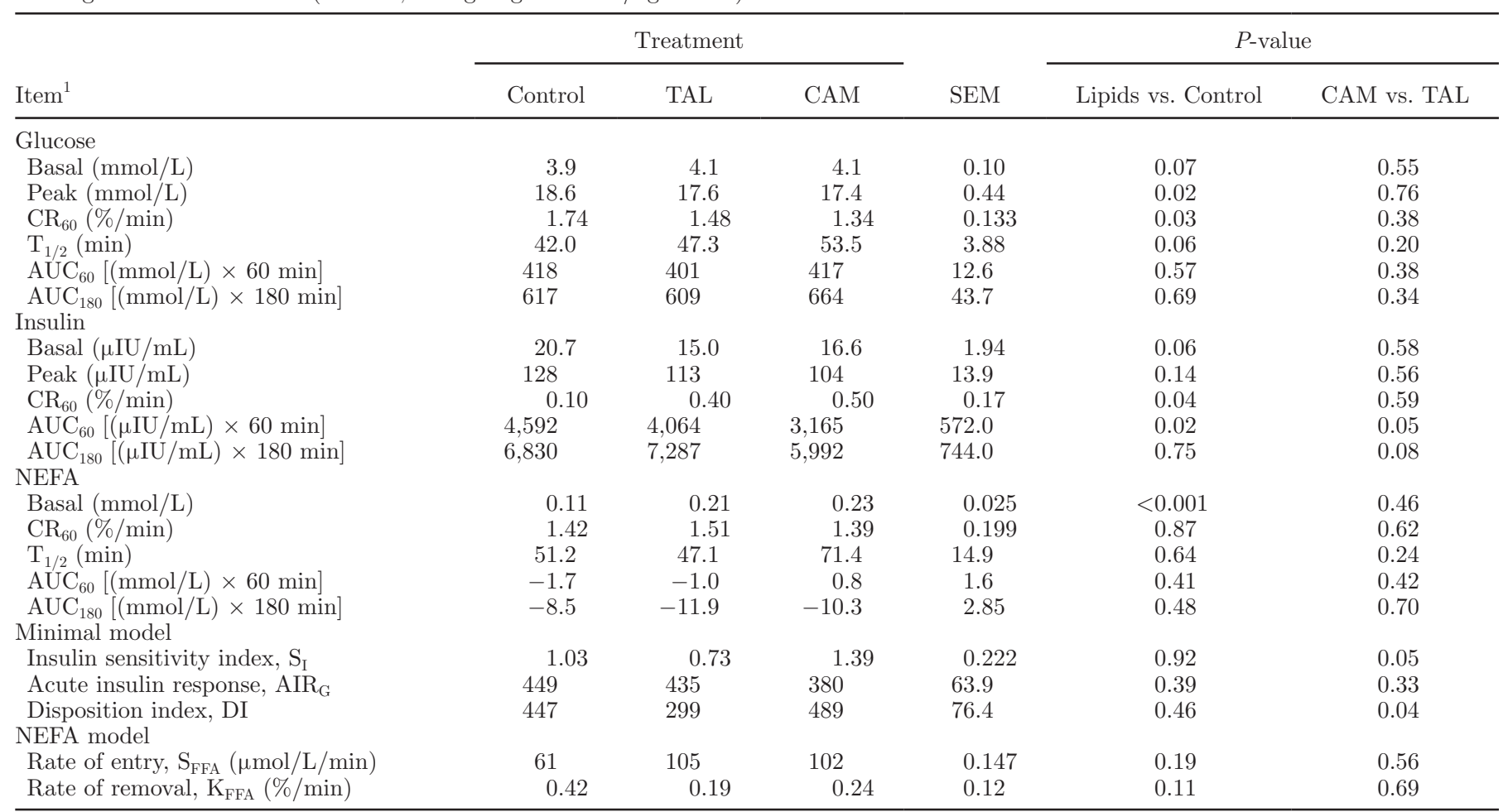

${ }^{1}$ Basal $=$ average concentration at 15 and 5 min before IVGTT; $\mathrm{CR}_{60}=$ clearance rate during first 60 min of IVGTT; $\mathrm{T}_{1 / 2}=$ time to reach $1 / 2$ concentration; $\mathrm{AUC}_{60}=$ area under the curve during the first 60 min of IVGTT; and $\mathrm{AUC}_{180}=\mathrm{AUC}$ during 180 min of IVGTT.

were increased during CAM infusions compared with TAL.

Basal plasma NEFA concentration was approximately 2-fold higher for TAL and CAM than for control $(P<0.001)$. No treatment effects were detected for lipid supplementation (lipids vs. control) or lipid source (CAM vs. TAL) on CR, $\mathrm{T}_{1 / 2}$, or AUC of plasma NEFA during IVGTT (Figure 1C). However, the NEFA model (Boston and Moate, 2008) parameter $\mathrm{K}_{\mathrm{FFA}}$ was numerically decreased $(P=0.11)$ for lipid infusions during IVGTT.

\section{Response to IC}

Treatment effects on metabolic responses during IC are shown in Table 7. Basal glucose concentration was not affected by lipid infusions or by lipid source. However, the lipid infusions impaired the clearance of glucose during IC. The nadir concentration of glucose was higher $(P=0.04)$ for lipid treatments and the absolute value of glucose response AUC during IC was decreased $(P<0.01$; Figure $2 \mathrm{~A})$. In addition, glucose CR during the first $30\left(\mathbf{C R}_{30}\right)$ min of IC was smaller and $\mathrm{T}_{1 / 2}$ greater during lipid infusions $(P=0.02)$.
Basal insulin concentration tended to be lower $(P=$ 0.09) for lipid infusions. Infusion of CAM affected insulin clearance during IC compared with TAL (Figure 2B). Insulin peak concentration for CAM tended to be lower $(P=0.07)$ and $\mathrm{CR}_{30}$ of insulin was decreased $(P$ $=0.02)$, leading to increased insulin $\mathrm{T}_{1 / 2}(P<0.01)$. Furthermore, the value of insulin AUC response during CAM infusion tended to be smaller $(P=0.08)$ during the first $30 \mathrm{~min}$ of IC, in contrast to TAL.

Basal plasma NEFA before IC was almost 3-fold higher for TAL and CAM than for control $(P<0.001)$. In addition, the absolute value of NEFA response AUC for lipid infusions was increased during IC $(P<0.01$; Figure 2C). We observed a tendency for a decreased $\mathrm{CR}_{30}$ of plasma NEFA for CAM $(P=0.09)$ compared with TAL.

\section{DISCUSSION}

The central aim of the study was to determine whether the elevation of plasma NEFA concentration by abomasal infusion of TAL or CAM affected whole-body insulin sensitivity and glucose tolerance as assessed by the data obtained during IVGTT and IC in nonlac- 

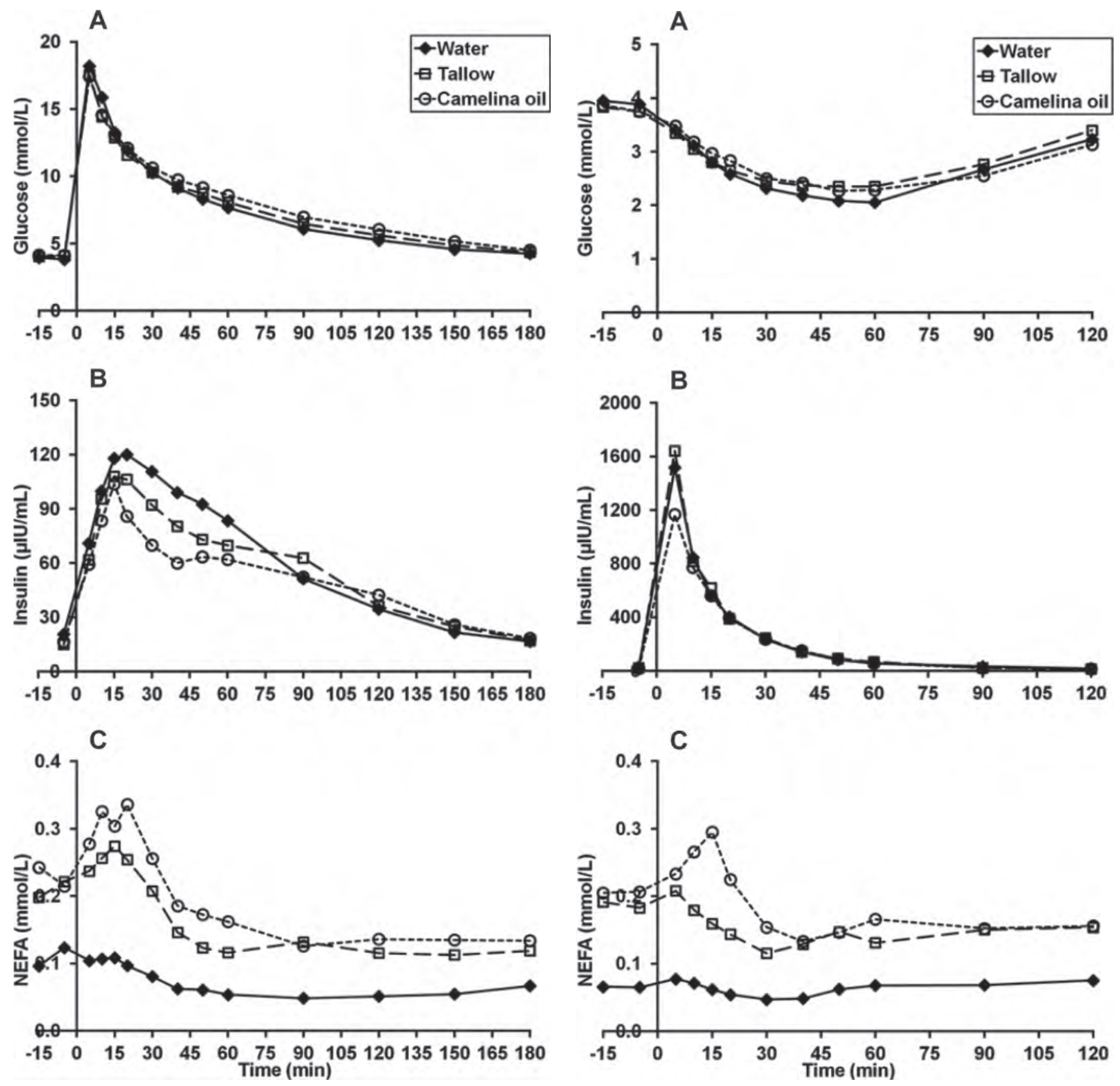

Figure 1. (A) Effect of abomasal infusion of water, tallow, or camelina oil (500 mL/d; $430 \mathrm{~g}$ of lipids/d) on plasma glucose (A), insulin (B), and (C) NEFA concentrations after i.v. glucose tolerance test (IVGTT; $0.25 \mathrm{~g}$ of glucose $/ \mathrm{kg}$ of BW). Energy intake was calculated to meet $95 \%$ of ME requirements of 8-mo-pregnant cows. Treatments were administered for $98 \mathrm{~h}$ before IVGTT.

tating, pregnant dairy cows. Another purpose of the experiment was to compare the effects of supplementing the cows with either a lipid source rich in C18:3n-3 (CAM) or TAL, the FA profile of which resembles that of a cow's fat deposits (Smith et al., 1978).

Figure 2. (A) Effect of abomasal infusion of water, tallow, or camelina oil $(500 \mathrm{~mL} / \mathrm{d} ; 430 \mathrm{~g}$ of lipids/d) on plasma glucose (A), insulin (B), and (C) NEFA concentrations after i.v. insulin challenge (IC; 0.1 IU of insulin $/ \mathrm{kg}$ of BW). Energy intake was calculated to meet $95 \%$ of ME requirements of 8-mo-pregnant cows. Treatments were administered for $108 \mathrm{~h}$ before IC.

The FA composition of TAL in the present study was similar to those used in previous studies (Mashek et al., 2005; Pires et al., 2007b; Brickner et al., 2009). Camelina oil had a high C18:3n-3 content, approximately $37 \%$ of total FA. Nevertheless, C18:3n-3 was 
Table 7. Effect of abomasal infusion of water (control), tallow (TAL), or camelina oil (CAM) on plasma glucose, insulin, and NEFA responses to insulin challenge (IC; 0.1 IU of insulin i.v. $/ \mathrm{kg}$ of BW)

\begin{tabular}{|c|c|c|c|c|c|c|}
\hline Item $^{1}$ & \multicolumn{3}{|c|}{ Treatment } & SEM & \multicolumn{2}{|c|}{$P$-value } \\
\hline Basal (mmol/L) & 3.9 & 3.8 & 3.8 & 0.16 & 0.22 & 0.88 \\
\hline Nadir $(\mathrm{mmol} / \mathrm{L})$ & 2.1 & 2.3 & 2.2 & 0.10 & 0.04 & 0.39 \\
\hline $\mathrm{CR}_{30}(\% / \min )$ & 1.19 & 0.82 & 0.97 & 0.08 & 0.02 & 0.17 \\
\hline $\mathrm{T}_{1 / 2}(\min )$ & 59.9 & 88.0 & 73.2 & 5.80 & 0.02 & 0.10 \\
\hline \multicolumn{7}{|l|}{ Insulin } \\
\hline Basal $(\mu \mathrm{IU} / \mathrm{mL})$ & 27.4 & 23.3 & 18.7 & 3.17 & 0.09 & 0.24 \\
\hline Peak $(\mu \mathrm{IU} / \mathrm{mL})$ & 1,517 & 1,643 & 1,168 & 169.2 & 0.57 & 0.07 \\
\hline $\mathrm{CR}_{30}(\% / \mathrm{min})$ & 9.13 & 9.85 & 6.99 & 0.928 & 0.54 & 0.02 \\
\hline $\mathrm{T}_{1 / 2}(\min )$ & 8.2 & 7.2 & 10.1 & 0.71 & 0.54 & $<0.01$ \\
\hline $\mathrm{AUC}_{30}[(\mu \mathrm{IU} / \mathrm{mL}) \times 30 \mathrm{~min}]$ & 18,081 & 18,874 & 16,119 & $11,35.6$ & 0.62 & 0.08 \\
\hline $\mathrm{AUC}_{120}[(\mu \mathrm{IU} / \mathrm{mL}) \times 120 \mathrm{~min}]$ & 21,422 & 22,539 & 20,014 & $15,60.8$ & 0.92 & 0.15 \\
\hline
\end{tabular}

${ }^{1}$ Basal $=$ average concentration at 15 and 5 min before $\mathrm{IC} ; \mathrm{CR}_{30}=$ clearance rate during the first 30 min of IC; $\mathrm{T}_{1 / 2}=$ time to reach $1 / 2$ concentration; $\mathrm{AUC}_{60}=$ area under the curve $(\mathrm{AUC})$ during the first 60 min of $\mathrm{IC} ; \mathrm{AUC}_{120}=\mathrm{AUC}$ during 120 min of $\mathrm{IC}$; and $\mathrm{AUC} 30=\mathrm{AUC}$ during the first $30 \mathrm{~min}$ of IC.

less abundant in CAM than in the linseed oil used in recent studies $(50 \%$ of total FA; Pires et al., 2007b; Brickner et al., 2009).

The pulse-dose technique of lipid infusions used in the current study proved to be successful in delivering the infusates into the abomasum, because the digestibility of EE was increased on average by $55 \%$ during the lipid infusions. In addition, the abomasal infusion of lipid sources had a significant effect on plasma LCFA composition. As anticipated, infusion of CAM significantly increased the percentage of PUFA (C18:2 and $\mathrm{C} 18: 3)$ and decreased the percentage of SFA and MUFA (C16:1 and C18:1) in plasma compared with TAL. This is in agreement with the study of Pires et al. (2008), in which fed, nonlactating, nongestating cows were abomasally infused with linseed oil or TAL for $5 \mathrm{~d}$. Moreover, a promoted elevation of plasma NEFA concentration measured from plasma samples on d 5 gives further evidence that lipid source modified profiles of plasma NEFA. However, NEFA concentration was not affected by lipid source, which is in accordance with Pires et al. (2008).

The plasma NEFA concentrations observed during lipid infusions were at the same level as those reported in dairy cows during the week preceding calving on grass-based silage diets with different energy and concentrate allowances (Kokkonen et al., 2004, 2005). Therefore, we speculate that the metabolic responses during IVGTT and IC in the current study might mirror the responses in close-up dry cows during the last week of pregnancy, when plasma NEFA concentrations are being elevated.

Abomasal infusion of TAL or CAM impaired glucose clearance during IVGTT, because glucose CR was decreased and time to reach half-maximal glucose concentration was increased during lipid infusions. This is in agreement with an earlier study in which i.v. infusion of TAL impaired glucose clearance during IVGTT in nonlactating, nongestating Holstein cows (Pires et al., 2007b). The impairment of glucose clearance during lipid treatments was also confirmed during IC, because the nadir glucose concentration and $\mathrm{T}_{1 / 2}$ were higher in lipid-treated cows, and $\mathrm{CR}$ and the absolute value of glucose response AUC were decreased compared with control.

Glucose uptake occurs by insulin-mediated glucose uptake (IMGU) in insulin-sensitive tissue and by noninsulin-mediated glucose uptake in both insulin-sensitive and insulin-insensitive tissues. The predominant glucose transporter responsible for IMGU in skeletal and cardiac muscle and adipose tissue is GLUT- 4 . Insulin stimulates the translocation of GLUT4 to the plasma membrane and, thereby, increases glucose transport activity (Zhou et al., 1999). Infusion of TAL and CAM significantly increased plasma NEFA concentrations during experimental periods in the present study. Acute NEFA elevation in rodents has been demonstrated to induce muscle insulin resistance in a few hours, with similar muscle lipid accretion as observed after prolonged high-fat-diet-induced insulin resistance 
(Kraegen et al., 2001). Moreover, excess release of NEFA from adipose tissue and accumulation of intracellular lipid impair insulin signaling in human skeletal muscle, leading to a decrease in insulin-stimulated glucose transport (Boden, 2011), which could also explain the impairment of IMGU in the current study. Holtenius et al. (2003) demonstrated that CR of glucose during IVGTT was decreased in overconditioned cows with higher plasma NEFA at calving compared with leaner cows. Further, insulin-stimulated glucose disposal rate was significantly decreased in nonlactating, nongestating Holstein cows after a 4-d fast to induce high NEFA concentrations (Oikawa and Oetzel, 2006), indicating decreased glucose disposal by peripheral tissues.

The basal insulin concentration tended to be lower and insulin $\mathrm{AUC}_{60}$ was decreased during IVGTT in lipid-treated cows. In contrast, insulin clearance increased during lipid infusions. It seems that the lower insulin concentration during IVGTT in lipid treatments resulted both from lower insulin secretion and from an increase in insulin clearance. Bossaert et al. (2008) showed that plasma NEFA concentrations were negatively correlated with insulin AUC and peak concentrations during the transition period in Holstein cows, suggesting that elevated NEFA concentrations may interfere with glucose-induced insulin secretion. In humans, it is well documented that transiently elevated NEFA have a tendency to enhance insulin secretion, whereas prolonged exposure to high NEFA tends to reduce insulin secretion (Rosen and Spiegelman, 2006). The lower basal insulin concentration during IVGTT might also partly result from decreased supply of glucogenic substrates to the liver, because the DMI of lipid-treated cows was approximately $1.3 \mathrm{~kg} / \mathrm{d}$ lower compared with control. However, Holtenius et al. (2003) showed no effect of low or medium (6 or $9 \mathrm{~kg} / \mathrm{d}$ ) DMI on plasma insulin response during IVGTT in latepregnant cows.

The parameters derived from the minimal model $\left(\mathrm{S}_{\mathrm{I}}\right.$ and DI) suggest that CAM had an insulin-sensitizing effect during IVGTT compared with TAL. The insulin sensitivity index, which represents the net capacity for insulin to promote glucose disposal (Moate et al., 2007) both by diminishing endogenous glucose production and by increasing glucose utilization (Bergman et al., 1987), was greater for CAM than for TAL. Moreover, numerically lower insulin concentrations during IC in CAM compared with TAL led to the same clearance of glucose, which gives further support to the insulinsensitizing effect of CAM. Abomasal infusion of linseed oil, rich in C18:3n-3, to fed, nonlactating, nongestating Holstein cows had a similar effect on insulin sensitivity during IVGTT compared with TAL infusion (Pires et al., 2008).
The DI was increased by CAM infusion in contrast to TAL infusion. Pancreatic $\beta$-cells are capable of upregulating insulin secretion in response to insulin resistance, and DI represents the extent of this action (Bergman, 2005 ). Results indicate that the $\beta$-cells of CAM-infused cows were able to more efficiently compensate for insulin resistance by increasing their responsivity. Human studies have shown that 24-h oral ingestion of SFA impairs $\beta$-cell function compared with ingestion of unsaturated FA, as a result of a failure in insulin secretion to compensate for insulin resistance (Xiao et al., 2006). Saturated C16:0 has also been shown to reduce the proliferative capacity of $\beta$-cells in rodents and induced $\beta$-cell death mainly by apoptosis (Maedler et al., 2001). Modification of plasma total LCFA profile during CAM infusion, especially the reduction of the percentage of SFA and a marked increase of PUFA, might have improved the functionality of the pancreatic $\beta$-cells in the present study.

During IVGTT and IC, we observed an initial increase in plasma NEFA concentration in lipid-treated cows until the antilipolytic action of insulin resulted in decreased NEFA concentration. The presence of a latency phase in NEFA response during IVGTT was previously reported in humans (Sumner et al., 2004) and in dairy cows in early lactation (Moate et al., 2007). This phase represents the time required for insulin to pass to the interstitium (Jansson et al., 1993) where it acts (Bergman et al., 1979) and raises the concentrations necessary to initiate the inhibition of lipolysis (Sumner et al., 2004). During the latency period, plasma NEFA concentrations remained constant or were even substantially increased (Moate et al., 2007), as in current data. However, the initial increase in plasma NEFA concentration was evident only during lipid treatments. Therefore, a plausible explanation for the initial increase in plasma NEFA during IVGTT and IC is that it results from a refractory phase, during which the level of NEFA is unresponsive to the changes produced by insulin. In conclusion, these results suggest that lipid infusions might have prolonged the time taken by the insulin to start exerting its antilipolytic effect.

Further, our results suggest that, compared with control, lipid treatments affected NEFA clearance during IVGTT. The mean fractional rate of utilization of NEFA $\left(K_{\mathrm{FFA}}\right)$ tended to decrease in lipid-treated cows during IVGTT. In a nonfasting situation, as in the current study, $\mathrm{K}_{\mathrm{FFA}}$, the rate constant of NEFA removal from the plasma pool, represents both the oxidation of FA by peripheral tissues and the sequestration of fatty acids in adipose tissue (Boston and Moate, 2008). Because we observed no treatment differences in the rate of provision of NEFA to the plasma pool $\left(\mathrm{S}_{\mathrm{FFA}}\right.$, 
which represents the potential maximum rate of lipolysis) during IVGTT, we concluded that NEFA clearance was impaired during TAL and CAM infusions. However, based on the present data, we cannot determine whether the impairment of NEFA removal by lipid infusions was due to lower uptake and oxidation of NEFA by lipid-utilizing tissues or to decreased incorporation of FA into adipose tissue.

The absolute value of NEFA AUC during IC was greater for lipid-treated cows compared with control, suggesting that both TAL and CAM infusions enhanced the antilipolytic effect of insulin during IC. However, Sechen et al. (1990) suggested that the antilipolytic effects of insulin are best evidenced during states of elevated plasma NEFA. In line with this, the present results demonstrate minor changes in the NEFA response curve during IVGTT and IC in water-treated (control) cows with low plasma NEFA concentrations. Therefore, the potential antilipolytic effect of lipid supplementation relative to control is difficult to assess based on NEFA CR and AUC of the present data. In contrast to the current study, Pires et al. (2008) found that abomasal infusion of linseed oil, compared with TAL, enhanced the antilipolytic effects of insulin in nonlactating, nonpregnant, feed-restricted Holstein cows. In the present study, the energy balance of cows was only slightly negative and, therefore, the plasma NEFA concentrations in all treatment groups were markedly lower than in the study by Pires et al. (2008). This may explain the discrepancy between the studies.

\section{CONCLUSIONS}

Elevation of plasma NEFA concentration by infusion of TAL or CAM impaired glucose clearance and tended to decrease insulin secretion during glucose tolerance test. Glucose clearance was also decreased during insulin challenge. These results indicate that elevated plasma NEFA concentrations impaired whole-body insulin sensitivity and glucose responsiveness in nonlactating Ayrshire dairy cows during late pregnancy. Further, the data support the hypothesis that insulin sensitivity was enhanced by abomasal infusion of CAM, suggesting that the pancreatic $\beta$-cells were able to more efficiently compensate for insulin resistance by increasing their responsivity during CAM infusions. In the present study, the plasma NEFA concentrations of the lipid-treated cows were at the same level as those previously reported in dairy cows during the week preceding calving, thus reflecting the role of increased NEFA concentration in the induction of whole-body insulin resistance with cows approaching parturition. Feeding practices, which either decrease the level of plasma NEFA or alter the
FA composition of NEFA, or both, may be useful tools in modifying insulin sensitivity of close-up dry cows.

\section{ACKNOWLEDGMENTS}

The authors gratefully appreciate the assistance of the staff at the research farm of Helsinki University (Viikki, Finland) for the care of experimental animals, under the supervision of head manager Juha Suomi, and that of the laboratory staff of the Department of Agricultural Sciences (University of Helsinki) for conducting the chemical and biological analysis. This study was partially funded by Raisio Feed Ltd. (Raisio, Finland), and the first author was financially supported by Raisio plc Research Foundation (Raisio, Finland).

\section{REFERENCES}

AOAC. 1995. Official Methods of Analysis. 16th ed. Association of Official Analytical Chemists, Arlington, VA.

Ayala, J. E., D. P. Bracy, O. P. McGuinness, and D. H. Wasserman. 2006. Considerations in the design of hyperinsulinemic-euglycemic clamps in the conscious mouse. Diabetes 55:390-397.

Barham, D., and P. Trinder. 1972. An improved color reagent for the determination of blood glucose by the oxidase system. Analyst (Lond.) 97:142-145.

Barker, S. B., and W. H. Summerson. 1941. The colorimetric determination of lactic acid in biological materials. J. Biol. Chem. 138:535-554.

Bell, A. W. 1993. Pregnancy and fetal metabolism. Pages 405-431 in Quantitative Aspects of Ruminant Digestion and Metabolism. J. M. Forbes and J. France, ed. CAB International, Wallingford, UK.

Bell, A. W. 1995. Regulation of organic nutrient metabolism during transition from late pregnancy to early lactation. J. Anim. Sci. 73:2804-2819.

Bell, A. W., and D. E. Bauman. 1997. Adaptations of glucose metabolism during pregnancy and lactation. J. Mammary Gland Biol. Neoplasia 2:265-278.

Bergman, R. N. 2005. Minimal model: Perspective from 2005. Horm. Res. 64(Suppl. 3):8-15.

Bergman, R. N., and C. R. Bowden. 1981. The minimal model approach to quantification of factors controlling glucose disposal in man. Pages 269-296 in Carbohydrate Metabolism. J. Wiley, New York, NY

Bergman, R. N., Y. Z. Ider, C. R. Bowden, and C. Cobelli. 1979. Quantitative estimation of insulin sensitivity. Am. J. Physiol. 236:E667-E677.

Bergman, R. N., R. Prager, A. Volund, and J. M. Olefsky. 1987. Equivalence of the insulin sensitivity index in man derived by the minimal model method and the euglycemic glucose clamp. J. Clin. Invest. $79: 790-800$.

Boden, G. 2011. Obesity, insulin resistance and free fatty acids. Curr. Opin. Endocrinol. Diabetes Obes. 18:139-143.

Boden, G., and X. Chen. 1995. Effects of fat on glucose uptake and utilization in patients with noninsulin-dependent diabetes. J. Clin. Invest. 96:1261-1268.

Bossaert, P., J. L. M. R. Leroy, S. De Vliegher, and G. Opsomer. 2008. Interrelations between glucose-induced insulin response, metabolic indicators, and time of first ovulation in high-yielding dairy cows. J. Dairy Sci. 91:3363-3371.

Boston, R. C., and P. J. Moate. 2008. A novel minimal model to describe NEFA kinetics following an intravenous glucose challenge. Am. J. Physiol. Regul. Integr. Comp. Physiol. 294:R1140-1147.

Boston, R. C., D. Stefanovski, P. J. Moate, A. E. Sumner, R. M. Watanabe, and R. N. Bergman. 2003. MINMOD Millennium: A 
computer program to calculate glucose effectiveness and insulin sensitivity from the frequently sampled intravenous glucose tolerance test. Diabetes Technol. Ther. 5:1003-1015.

Brickner, A. E., J. A. A. Pires, T. F. Gressley, and R. R. Grummer. 2009. Effects of abomasal lipid infusion on liver triglyceride accumulation and adipose lipolysis during fatty liver induction in dairy cows. J. Dairy Sci. 92:4954-4961.

Drackley, J. K. 1999. Biology of dairy cows during the transition period: The final frontier? J. Dairy Sci. 82:2259-2273.

Dresner, A., D. Laurent, M. Marcucci, M. E. Griffin, S. Dufour, G. W. Cline, L. A. Slezak, D. K. Andersen, R. S. Hundal, D. L. Rothman, K. F. Petersen, and G. I. Shulman. 1999. Effects of free fatty acids on glucose transport and IRS-1 associated phosphatidylinositol 3-kinase activity. J. Clin. Invest. 103:253-259.

Fedor, D., and D. S. Kelley. 2009. Prevention of insulin resistance by n-3 polyunsaturated fatty acids. Curr. Opin. Clin. Nutr. Metab. Care 12:138-146.

Ferrannini, E., and A. Mari. 1998. How to measure insulin sensitivity. J. Hypertens. 16:895-906.

Grummer, R. R. 1993. Etiology of lipid-related metabolic disorders in periparturient dairy cows. J. Dairy Sci. 76:3882-3896.

Hayirli, A. 2006. The role of exogenous insulin in the complex of hepatic lipidosis and ketosis associated with insulin resistance phenomenon in postpartum dairy cattle. Vet. Res. Commun. 30:749-774

Holtenius, K., S. Agenas, C. Delavaud, and Y. Chilliard. 2003. Effects of feeding intensity during the dry period. 2. Metabolic and hormonal responses. J. Dairy Sci. 86:883-891.

Huhtanen, P. J., R. Blauwiekel, and I. Saastamoinen. 1998. Effects of intraruminal infusions of propionate and butyrate with two different protein supplements on milk production and blood metabolites in dairy cows receiving grass silage-based diet. J. Sci. Food Agric. $77: 213-222$.

Huida, L., H. Väätäinen, and M. Lampila. 1986. Comparison of dry matter contents in grass silages as determined by oven drying and gas chromatographic water analysis. Ann. Agric. Fenn. 25:215230 .

Jansson, P. A., J. P. Fowelin, H. P. v. Schenck, U. P. Smith, and P. N. Lönnroth. 1993. Measurement by microdialysis of the insulin concentration in subcutaneous interstitial fluid. Diabetes 42:1469-1473.

Kahn, C. R. 1978. Insulin resistance, insulin sensitivity and insulin unresponsiveness: A necessary distinction. Metabolism 27:1893 1902.

Kokkonen, T., J. Taponen, T. Anttila, L. Syrjälä-Qvist, C. Delavaud, Y. Chilliard, M. Tuori, and A. T. Tesfa. 2005. Effect of body fatness and glucogenic supplement on lipid and protein mobilization and plasma leptin in dairy cows. J. Dairy Sci. 88:1127-1141.

Kokkonen, T., A. T. Tesfa, M. Tuori, and L. Syrjälä-Qvist. 2004. Concentrate feeding strategy of dairy cows during the transition period. Livest. Prod. Sci. 86:239-251.

Kraegen, E. W., G. J. Cooney, J. M. Ye, A. L. Thompson, and S. M. Furler. 2001. The role of lipids in the pathogenesis of muscle insulin resistance and beta cell failure in type II diabetes and obesity. Exp. Clin. Endocrinol. Diabetes 109(Suppl. 2):S189-S201.

LeBlanc, S. J., T. Herdt, W. Seymour, T. Duffield, and K. Leslie. 2004. Factors associated with peripartum serum concentrations of vitamin E, retinol, and $\beta$-carotene in Holstein dairy cattle, and their associations with periparturient disease. J. Dairy Sci. 87:609-619.

LeBlanc, S. J., K. E. Leslie, and T. D. Duffield. 2005. Metabolic predictors of displaced abomasum in dairy cattle. J. Dairy Sci. 88:159-170.

Lombardo, Y. B., and A. G. Chicco. 2006. Effects of dietary polyunsaturated n-3 fatty acids on dyslipidemia and insulin resistance in rodents and humans: A review. J. Nutr. Biochem. 17:1-13.

Luo, J., S. W. Rizkalla, J. Boillot, C. Alamowitch, H. Chaib, F. Bruzzo, N. Desplanque, A.-M. Dalix, G. Durand, and G. Slama. 1996. Dietary (n-3) polyunsaturated fatty acids improve adipocyte insulin action and glucose metabolism in insulin-resistant rats: Relation to membrane fatty acids. J. Nutr. 126:1951-1958.

Maedler, K., G. A. Spinas, D. Dyntar, W. Moritz, N. Kaiser, and M. Y. Donath. 2001. Distinct effects of saturated and monoun- saturated fatty acids on beta-cell turnover and function. Diabetes 50:69-76.

MAFF. 1975. Energy Allowance and Feeding System for Ruminants. Tech. Bull., vol. 33. Her Majesty's Stationery Office, London, UK.

Mashek, D. G., S. J. Bertics, and R. R. Grummer. 2005. Effects of intravenous triacylglycerol emulsions on hepatic metabolism and blood metabolites in fasted dairy cows. J. Dairy Sci. 88:100-109.

Moate, P. J., J. R. Roche, L. Chagas, and R. C. Boston. 2007. Evaluation of a compartmental model to describe non-esterified fatty acid kinetics in Holstein dairy cows. J. Dairy Res. 74:430-437.

Morgan, C. R., and A. Lazarow. 1963. Immunoassay of insulin: Two antibody system, plasma insulin levels of normal, subdiabetic and diabetic rats. Diabetes 12:115-126.

MTT Agrifood Research Finland. 2006. Finnish feed tables and feeding recommendations: 2006. Accessed Aug. 15, 2009. http://www. mtt.fi/mtts/pdf/mtts106.pdf.

Muniyappa, R., S. Lee, H. Chen, and M. J. Quon. 2008. Current approaches for assessing insulin sensitivity and resistance in vivo: Advantages, limitations, and appropriate usage. Am. J. Physiol. Endocrinol. Metab. 294:E15-E26.

Nousiainen, J., M. Rinne, M. Hellämäki, and P. Huhtanen. 2003. Prediction of the digestibility of the primary growth of grass silages harvested at different stages of maturity from chemical composition and pepsin-cellulase solubility. Anim. Feed Sci. Technol. 103:97-111.

Oikawa, S., and G. R. Oetzel. 2006. Decreased insulin response in dairy cows following a four-day fast to induce hepatic lipidosis. J. Dairy Sci. 89:2999-3005.

Ospina, P. A., D. V. Nydam, T. Stokol, and T. R. Overton. 2010 Evaluation of nonesterified fatty acids and $\beta$-hydroxybutyrate in transition dairy cattle in the northeastern United States: Critical thresholds for prediction of clinical diseases. J. Dairy Sci. 93:546-554.

Overton, T. R., and M. R. Waldron. 2004. Nutritional management of transition cows: Strategies to optimize metabolic health. J. Dairy Sci. 87(E-Suppl.):E105-E119.

Pethick, D. W., A. W. Bell, and E. F. Annison. 1984. Fats as energy sources in animal tissues. Pages 225-248 in Fats in Animal Nutrition. J. Wiseman, ed. Butterworths, London, UK.

Petterson, J. A., F. R. Dunshea, R. A. Ehrhardt, and A. W. Bell. 1993. Pregnancy and undernutrition alter glucose metabolic responses to insulin in sheep. J. Nutr. 123:1286-1295.

Pires, J. A. A., J. B. Pescara, A. E. Brickner, N. Silva del Rio, A. P. Cunha, and R. R. Grummer. 2008. Effects of abomasal infusion of linseed oil on responses to glucose and insulin in Holstein cows. J. Dairy Sci. 91:1378-1390.

Pires, J. A. A., J. B. Pescara, and R. R. Grummer. 2007a. Reduction of plasma NEFA concentration by nicotinic acid enhances the response to insulin in feed-restricted Holstein cows. J. Dairy Sci. 90:4635-4642.

Pires, J. A. A., A. H. Souza, and R. R. Grummer. 2007b. Induction of hyperlipidemia by intravenous infusion of tallow emulsion causes insulin resistance in Holstein cows. J. Dairy Sci. 90:2735-2744.

Rosen, E. D., and B. M. Spiegelman. 2006. Adipocytes as regulators of energy balance and glucose homeostasis. Nature 444:847-853.

Sechen, S. J., F. R. Dunshea, and D. E. Bauman. 1990. Somatotropin in lactating cows: Effect on response to epinephrine and insulin. Am. J. Physiol. 258:E582-E588.

Shiang, K.-H. 2004. The SAS ${ }^{\circledR}$ calculations of areas under the curve (AUC) for multiple metabolic readings. Western users of SAS Software presentation, Pasadena 15.10.2004. Accessed Feb. 20, 2010 http://www.lexjansen.com/wuss/2004/posters/c_post_the_sas_ calculations_.pdf.

Shukla, K. S., P. C. Dutta, and W. E. Artz. 2002. Camelina oil and its unusual cholesterol content. J. Am. Oil Chem. Soc. 79:965-969.

Smith, N. E., W. L. Dunkley, and A. A. Franke. 1978. Effects of feeding protected tallow to dairy cows in early lactation. J. Dairy Sci. 61:747-756

Steil, G. M., J. Murray, R. N. Bergman, and T. A. Buchanan. 1994. Repeatability of insulin sensitivity and glucose effectiveness from 
the minimal model. Implications for study design. Diabetes 43:1365-1371.

Storlien, L. H., J. A. Higgins, T. C. Thomas, M. A. Brown, H. Q. Wang, F. Huang, and P. L. Else. 2000. Diet composition and insulin action in animal models. Br. J. Nutr. 83(Suppl. 1):S85-S90.

Storlien, L. H., A. B. Jenkins, D. J. Chisholm, W. S. Pascoe, S. Khouri, and E. W. Kraegen. 1991. Influence of dietary fat composition on development of insulin resistance in rats. Relationship to muscle triglyceride and omega-3 fatty acids in muscle phospholipid. Diabetes 40:280-289.

Sumner, A. E., R. N. Bergman, G. L. Vega, D. J. Genovese, C. S. Cochran, K. Pacak, R. M. Watanabe, and R. C. Boston. 2004 The multiphasic profile of free fatty acids during the intravenous glucose tolerance test is unresponsive to exogenous insulin. Metabolism 53:1202-1207.

Trinder, P. 1969. Determination of glucose in blood using glucose oxidase with an alternative oxygen acceptor. Ann. Clin. Biochem. $6: 24-28$.

van Keulen, J., and B. A. Young. 1977. Evaluation of acid-insoluble ash as a marker in ruminant digestibility studies. J. Anim. Sci. 44:282-287.
Van Soest, P. J., J. B. Robertson, and B. A. Lewis. 1991. Methods for dietary fiber, neutral detergent fiber, and nonstarch polysaccharides in relation to animal production. J. Dairy Sci. 74:3583-3597.

Weekes, T. E. 1991. Hormonal control of glucose metabolism. Pages 183-200 in Physiological Aspects of Digestion and Metabolism in Ruminants. T. Tsuda, Y. Sasaki, and R. Kawashima, ed. Academic Press, San Diego, CA.

Xiao, C., A. Giacca, A. Carpentier, and G. F. Lewis. 2006. Differential effects of monounsaturated, polyunsaturated and saturated fat ingestion on glucose-stimulated insulin secretion, sensitivity and clearance in overweight and obese, nondiabetic humans. Diabetologia 49:1371-1379.

Zhou, L., H. Chen, P. Up, L. N. Cong, S. Sciacchitano, Y. Li, D. Graham, A. R. Jacobs, S. I. Taylor, and M. J. Quon. 1999. Action of insulin receptor subtrate-2 (IRS-3) and IRS-4 to stimulate translocation of GLUT4 in rat adipose cells. Mol. Endocrinol. 13:505-514. 